\title{
AlienaÇão, Exteriorização e Reflexão eM Hegel e MarX ${ }^{1}$
}

\author{
Agemir Bavaresco $^{2}$; Christian Iber ${ }^{3}$; Eduardo Garcia Lara ${ }^{4}$ \\ (Pontifícia Universidade Católica do Rio Grande do Sul)
}

\section{Introduçãa ${ }^{5}$}

A teoria da reflexão, que Hegel desenvolve no $1 .^{\circ}$ capítulo da lógica da essência, desempenha um papel ontológico e epistemológico na teoria marxiana do trabalho alienado e na teoria da propriedade privada nos Manuscritos econômico-filosóficos (1844). Qual é o ponto de comparação entre a teoria da reflexão hegeliana e marxiana? É a teoria da alienação. Em Hegel temos a alienação do pensar no pensar reflexionante, ou seja, no modo de operar do entendimento; e em Marx temos a alienação do trabalho sob as condições da propriedade privada. Marx defende, sobretudo nos Manuscritos (1844), uma teoria da exteriorização do trabalho. O trabalho como atividade tem para Marx, tal como a atividade do espírito e do pensar em Hegel, a estrutura da negatividade, isto é, da exteriorização e do retorno da exteriorizão para dentro de si mesma. Porém, a alienação do trabalho impede que o trabalho como exteriorização possa efetuar seu retorno para

1 Uma versão preliminar do presente artigo foi publicada em Iber, Christian; Lara, Eduardo Garcia; Bavaresco, Agemir. Teoria da reflexão como alienação em Hegel e Marx. In: Bavaresco, A.; Pontel, E.; Tauchen, J. (Orgs.). De Kant a Hegel. Leituras e Atualizações. Porto Alegre: Editora Fi, 2019, pp. 341-364.

2 abavaresco@pucrs.br.

3 christian.iber@yahoo.de.

4 eduardo-g-1@hotmail.com.

5 Agradecemos a leitura rigorosa, as observações críticas e as sugestões interpretativas de Federico Orsini.

Philosophica, 54, Lisboa, 2019, pp. 99-118. 
dentro de si mesmo. O trabalho se torna exteriorizado, sai de si e permanece fora de si, pois é apropriado pela propriedade privada.

(i) Apresentamos, inicialmente, a teoria da reflexão hegeliana. A tese de que a lógica da essência é uma teoria da alienação do pensar implica que a lógica da reflexão trata de uma teoria da exteriorização e do retorno da exteriorização, mas de um retorno que permanece deficitário ou incompleto. Isso significa que nas determinações de reflexão, como são apresentadas pelas leis do pensar da lógica tradicional, a reflexão está fora de si. Elas são determinações alienadas do pensar especulativamente dialético. Para Hegel, a lógica formal, enquanto segue as leis do pensar, simplesmente não pensa. Se a lógica formal opera com um pensar que não pensa, isso é uma contradição. Diferentemente do pensar da lógica formal (reflexão externa do entendimento subjetivo) a reflexão determinante (reflexão objetiva) permanece reflexão também em face das suas determinações alienadas. A reflexão determinante abre, portanto, uma dupla dimensão: a da lógica formal e, ao mesmo tempo, a da crítica à lógica formal. Trata-se de uma autocrítica da reflexão exteriorizada de modo alienado nas determinações de reflexão, isto é, uma autocrítica da reflexão alienada na forma do entendimento reflexionante.

(ii) Depois, explicitamos a teoria da alienação marxiana. Para Marx, a alienação não se relaciona apenas com o pensar ou com o espírito, ${ }^{6}$ mas com as relações materiais entre indivíduos que constituem a sociedade. A norma imanente ${ }^{7}$ - afirma Marx - é o estar junto a si mesmo do ser humano no seu outro, tanto no pensar como na realidade social. Nesse caso, o outro significa a efetividade objetiva que está configurada pela sociedade. Essa norma imanente da realidade social implica uma crítica ao trabalho alienado, que produz a propriedade privada que apropria os resultados do trabalho dos quais os trabalhadores estão excluídos. A relação excludente do trabalho alienado e da propriedade privada é uma oposição que se desenvolve no sentido da contradição, sendo esta uma relação que tende à dissolução.

(iii) Enfim, apresentamos aproximações e diferenças entre Hegel e Marx. Enquanto Hegel defende um idealismo realista, Marx sustenta um realismo idealista. Embora Hegel não negue a realidade independente do pensar, este tem a primazia, porque é capaz de configurá-la. Para Marx,

6 O espírito é, para Hegel, um sujeito supraindividual, acima do nível individual; para Marx, o verdadeiro sujeito são os indivíduos.

7 O pensar e a realidade social têm uma finalidade imanente: verdade e reconciliação que para Hegel e Marx têm a estrutura do estar junto a si mesmo no seu outro. Essa finalidade imanente pode ser designada como "norma imanente". 
o mundo objetivo não pode ser um produto da criatividade do conceito teórico. $\mathrm{O}$ mundo objetivo apenas pode ser mudado pela prática. Isso significa que a racionalidade do mundo e a sua reflexividade não são o produto do conceito, mas da prática social.

\section{A reflexão absoluta como movimento circular}

Na Doutrina da Essência (Hegel 2017), Hegel apresenta a teoria da reflexão como unidade da aparência e da essência, ou seja, "a aparência é o mesmo que a reflexão" e "a essência é reflexão" (id. pp. 42-43). A reflexão em sentido absoluto é explicada assim: "o movimento do nada para o nada, e, através disso, de retorno a si mesmo" (p. 43). Trata-se de um movimento circular que é imanente, uma negatividade pura em que nada está fora ou exterior, mas tudo está num movimento reflexivo interior. $\mathrm{O}$ movimento da reflexão desdobra-se em três momentos: ponente, exterior e determinante.

\subsection{Circularidade desenvolvida: a reflexão ponente como unidade} do pôr e do pressupor

$\mathrm{O}$ conceito de reflexão hegeliano não é uma reflexão subjetiva da consciência, nem uma reflexão do entendimento, mas uma estrutura lógico-objetiva de todo o efetivo. A reflexão ponente tem a estrutura lógica da reflexão absoluta, isto é, o movimento do nada para o nada. A essência reflexiva junta-se consigo como igualdade imediata, uma igualdade que é negativa. Então, a reflexão é a unidade da negatividade e da imediatidade, ou seja, é a dialética da negatividade que se relaciona consigo mesma.

A reflexão ponente se desdobra na dialética do pôr e do pressupor. O ser posto é o produto do retorno para dentro de si da essência enquanto reflexão. A reflexão é pôr como retornar, ou seja, é o negativo que se relaciona consigo e, ao mesmo tempo, é negação de si mesmo. Ao negar o negativo (enquanto pôr) a reflexão é pressupor. Então, temos a reflexão que é pôr e pressupor. O pôr tem a estrutura da negação como retorno do negativo para dentro de si mesmo: esta é a atividade da reflexão. A estrutura da negação como pressupor resulta daquela do pôr, pois a reflexão suprassume o pôr em seu pôr. "O retorno da essência é seu repelir-se de si mesma. Ou seja, a reflexão dentro de si é essencialmente o pressupor daquilo a partir do qual ela é o retorno" (Hegel 2017, p. 45, §5). A reflexão, ao se repelir de si, pressupõe-se e, então, retorna para dentro de si. Este é o jogo dialético do pôr da reflexão e do pressupor como repelir-se para retornar dentro de si. Aqui ocorre a duplicação da reflexão a que Hegel chama movimento reflexionante, enquanto "contrachoque absoluto dentro de si mesmo" 
(id., p. 46, §7). Trata-se de um movimento de progressão que se volta imediatamente para dentro de si mesmo, ou seja, é um automovimento do pensamento como unidade do pôr e pressupor, como um movimento circular de ir e vir incessantemente. Esse movimento é destituído de substrato; e nessa circularidade da reflexão ponente que se relaciona dentro do outro apenas consigo mesmo, há, ao mesmo tempo, um déficit que impede de pensar uma relação de alteridade efetiva. Porém, como a estrutura da essência é a reflexão circular, ela contém a negatividade dentro de si, capaz de romper a própria estrutura da reflexão ponente e de aparecer, então, como reflexão exterior (ver Iber 2018a, pp. 5-8). A reflexão se torna exterior e alheia a si, na medida em que se opõe a um imediato, a outro, com o qual se relaciona externamente.

\subsection{Exteriorização da reflexão: a reflexão exterior}

$\mathrm{Na}$ Observação a respeito da reflexão exterior, Hegel refere-se ao modo como a reflexão é habitualmente compreendida, isto é, como uma atividade subjetiva. Hegel diz: "O que a reflexão externa determina e põe no imediato são, neste aspecto, determinações externas ao mesmo", isto é, ao imediato pressuposto. A reflexão externa age sobre o imediato dado como uma forma que molda o conteúdo e a matéria a partir de fora.

A reflexão exterior se relaciona negativamente consigo e se relaciona com um outro que tem um caráter de substrato real. Na reflexão exterior, a reflexão está exteriorizada e duplicada, enquanto tem um outro pressuposto, com o qual se relaciona externamente. Assim, criou-se uma situação em que a reflexão está diante de si como exteriorizada, porque o outro ou imediato com o qual se relaciona não aparece mais como seu produto. Aqui temos a alteridade ou dualidade entre a reflexão e seu outro que forma $o$ modelo para a estrutura da consciência natural. ${ }^{8}$

8 Cabe destacar que a lógica de Hegel é sempre uma apresentação especulativamente dialética de formas não especulativas do pensar. Assim, a reflexão exterior não é idêntica à consciênica intencional do objeto da consciência natural, mas explica a estrutura intencional da consciência natural de modo dialético perante o pano de fundo da duplicação e da exteriorização da reflexão que conduz à reflexão exterior.

Há uma diferença entre a Fenomenologia e a Lógica no que diz respeito ao movimento de "alienação": A Fenomenologia mostra tanto o caminho para dentro da alienação quanto a saída da alienação. No sentido epistemológico, a oposição da consciência já é uma exteriorização de modo alienado. $\mathrm{O}$ espírito que se aliena no sentido mais estrito (Ver Fenomenologia: B. O espírito alienado de si. A cultura) se refere à Idade Média e à modernidade inicial. Porém, com a sociedade civil e o Estado moderno, a alienação começa a ser suprassumida. No saber absoluto, como saber verdadeiro que é o princípio da lógica, a alienação é completamente suprassumida. 


\subsection{Transição para a reflexão determinante: imersão da reflexão} no seu outro

Na reflexão ponente não se alcança a autossubsistência do ser posto, pois ela é imediatamente suprassumida. Porém, na reflexão exterior o imediato se torna o outro imediato: o pressuposto. $\mathrm{O}$ imediato obtém subsistência com a duplicação da reflexão. Como é que essa situação é superada? A superação não ocorre pela retirada da exteriorização, mas pela transformação da exteriorização na auto-exteriorização. "A autorrenúncia (negar do negar) da reflexão é um pôr extraordinário, pelo qual a reflexão se determina ela mesma como idêntica ao seu objeto, ao imediato. A reflexão que nega a si mesma e a imediatidade, ambas estão postas como idênticas no lado da imediatidade" (Iber 2018b, p. 3), ou seja, não mais distintas, uma imediatidade essencial. Aqui, a reflexão exterior está superada em relação ao imediato, pois a reflexão se torna imanente no outro, ou seja, "a exteriorização da reflexão exterior é a imersão da reflexão no imediato" (id., p. 4).

$\mathrm{O}$ avanço em relação à reflexão exterior não se dá pelo retorno à reflexão ponente, mas pelo aprofundamento de sua exterioridade. Trata-se de manter a autossubsistência da imediatidade e de não suprassumi-la na unidade em si da reflexão ponente. A reflexão se instancia, agora, na própria imediatidade pressuposta. "O objetivo é que a reflexão se reencontre dentro do outro, ou seja, superar a exterioridade juntando-se com o imediato". Em outras palavras, "a unificação da reflexão e da imediatidade realiza-se na própria imediatidade" (Iber 2018b, p. 2). A reflexão torna-se assim seu próprio outro, isto é, ela é uma "reflexão imanente da própria imediatidade" (Hegel 2017 , p. 48), uma reflexão que existe no outro. Imediatidade e reflexão coincidem no lado do ser posto. Com isso acentua-se a exterioridade, que terá primazia no desenvolvimento da essência. Porém, a exterioridade se despoja de seu dualismo, uma vez que ela subsiste unida como “imediatidade essencial” (Hegel 2017, p. 47). Então, a reflexão não é mais exterior, mas imanente à própria imediatidade. A reflexão que é em si e para si seu outro será a reflexão determinante (ver Iber 2018b, pp. 1-2). Em outras palavras, a objetividade enquanto exterioridade carrega em si a interioridade da reflexão. Esta imersão da reflexão no imediato pressuposto é, ao mesmo tempo, o sair de si da reflexão, isto é, a auto-exteriorização da reflexão.

Quanto ao conceito de alienação na lógica da essência, Hegel apresenta a crítica da alienação da reflexão. Isso implica desde já uma saída da alienação que será completa apenas na passagem para a lógica do conceito. 
Esquema (Iber 2018b, p. 4):

\begin{tabular}{|l|l|}
\hline I. Reflexão exterior & $\rightarrow$ o imediato \\
\hline $\begin{array}{l}\text { II. Reflexão põe-se no outro: } \\
\text { Junta-se consigo no imediato }\end{array}$ & $\begin{array}{l}\rightarrow \text { “a imediatidade essencial”: a } \\
\text { reflexão é imanente ao imediato }\end{array}$ \\
\hline III. Reflexão determinante & $\begin{array}{l}\rightarrow \text { a reflexão existe como ser } \\
\text { posto que é reflexão dentro de si: } \\
\text { a determinação da reflexão ou a } \\
\text { reflexão determinante }\end{array}$ \\
\hline
\end{tabular}

A tese principal é a seguinte: a reflexão exterior é superada assim que a reflexão se torna a si mesma externa. Ela existe somente como reflexão imanente ao seu outro. A reflexão não se torna exterior como na reflexão exterior, mas exterior a si mesma, isto é, ela se torna alheia a si mesma, vem para fora de si, existe apenas como determinação de reflexão. Hegel se expressa da seguinte maneira: "a reflexão determinante é a reflexão que veio para fora de si; a igualdade da essência consigo mesma está perdida na negação, que é o que domina" (Hegel 2017, p. 51).

\subsection{A reflexão determinante e a determinação de reflexão como ser} posto refletido dentro de si

A reflexão determinante é apresentada por Hegel em três ítens: 1. Resumo da reflexão ponente e exterior. 2. A determinação de reflexão como ser posto autorreflexivo. 3. A estrutura relacional da determinação de reflexão (ver Iber 2018c, pp. 1-6).

1. A reflexão determinante é a unidade da reflexão ponente e da reflexão exterior. A ponente apenas põe o outro como uma alteridade efêmera que desaparece imediatamente, pois é uma autorrelação negativa da reflexão. $\mathrm{Ou}$ seja, é uma imediatidade da reflexão que é, imediatamente, suprassumida. Porém, com a reflexão determinante emerge a unidade da reflexão ponente com a reflexão exterior. Hegel apresenta a correspondência entre o ser aí (Dasein) da esfera do ser com o ser posto (Gestztsein) na esfera da essência. O ser aí contém a negação de modo imediato, enquanto o ser posto é a imediatidade refletida, portanto suprassumida pela negatividade. O ser aí torna-se um ser posto através da constituição da negatividade da essência. Ou seja, o ser aí é silogizado pela essência. O ser posto é, então, superior em relação ao ser aí, porque o ser posto é a explicitação do processo da reflexão objetiva da essência. O ser aí na esfera do ser é o ser posto na 
lógica da essência. "O ser aí é apenas ser posto; essa é a proposição da essência do ser aí" (Hegel 2017, p. 50).

2. A determinação da reflexão é o ser posto que se reflete dentro de si, pois consegue reunir em si a reflexão ponente e exterior como o todo da reflexão, absorvendo-a como seu produto. A determinidade no ser é diferente da determinação da reflexão na essência. Hegel afirma que ambas são determinidades em relação ao outro, mas a determinidade do ser posto da essência é reflexão dentro de si, isto é, trata-se de uma determinação correlativa que, na medida em que se relaciona com a outra, é ao mesmo tempo independente.

$\mathrm{Na}$ categoria da qualidade, o ser determinado é apresentado como negação do outro. Porém, é uma negação desigual, porque a qualidade é um passar incessante para o outro, incapaz de se igualar em si. Ao contrário, a determinação de reflexão tem no ser posto a reflexão dentro de si e não é, por isso, desigual a si dentro de si mesma, a "determinidade essencial" (Hegel 2018, p. 51). Ou seja, na lógica da essência a relação reflexiva do ser posto é igual a si mesma, não é um passar para o outro como ocorria na lógica do ser da qualidade, que é um passar incessante para outro. O ser posto subsiste em si mesmo, refletindo-se como correlativo essencial.

Por causa da perda da unidade da essência nas determinações de reflexão, alcançamos um ponto em que estas (identidade, diferença, contradição e fundamento) aparecem como "essencialidades livres", ou seja, essencialidades abstratas e formais, sem a tensão dialética imanente - separadas, portanto, pela abstração do entendimento.

As determinações de reflexão são produtos da reflexão determinante e constituem a aparência da essência de modo determinado. Então, a reflexão é dominada pelo seu outro posto como negação, ou seja, a reflexão saiu de si e se alienou no outro. A reflexão determinante é como pôr um "pressupor absoluto" (Hegel 2017, p. 50): a reflexão se identifica com o seu outro, de tal modo que ela existe somente no seu outro. Por causa disso, ela não aparece como fundamento das determinações de reflexão, e estas afirmam-se como um fato originário da razão (ver Iber 2018c, p. 4).

A determinação da reflexão tem dois lados em tensão dentro da essência: (i) De um lado, o ser posto como mero negativo da unidade consigo mesma da essência. A reflexão permanece uma essência que não sai de si e as diferenças são postas, isto é, retomadas novamente dentro da essência. (ii) O outro lado é a reflexão dentro de si em que as diferenças não são postas como outro, mas refletidas dentro de si em igualdade compacta consigo. O que temos, então, é a essência dividida, ou seja, ela ficou dominada pelo ser posto refletido dentro de si. Ela irá carregar essa predominância 
da perda da unidade da essência ao longo de todo o percurso lógico da identidade, diferença e contradição. Hegel explicitará as determinações de reflexão como predomínio alienante da negação ou do ser posto refletido dentro de si sobre a unidade da reflexão. As determinações de reflexão são formas abstratas ou formais de explicação de uma coisa, porque dentro delas o ponto de referência da essência plena de conteúdo substancial ainda não está presente. Por isso, as determinações de reflexão são submetidas à dialética até alcançar a contradição, onde serão dissolvidas para encontrar, novamente, no fundamento, a unidade que perderam no início (ver Iber 2018c, p. 4, nota 1).

3. A estrutura relacional da determinação da reflexão: Hegel explica o conceito de determinação de reflexão em três passos: (1) A determinação de reflexão constitui-se no ser posto e na reflexão dentro de si. O ser posto e a reflexão dentro de si são momentos diversos que, na sua unidade, constituem a determinação de reflexão. (2) Como reflexão dentro de si, a determinação de reflexão tem autossubsistência. Como ser posto, ela é um momento negativo numa relação com outro. Ela é uma determinação correlativa que é autossubsistente na sua relação com a outra. (3) Depois, porque a determinação de reflexão é unidade do ser posto e da reflexão dentro de si, ela se relaciona com o outro nela mesma, inclui esse dentro de si, e como reflexão consigo mesmo suprassume o seu ser posto e exclui o seu correlato. "Com isso, as determinações de reflexão geram a aparência da sua fixação absoluta uma contra a outra, que, na sequência, será submetida a uma crítica lógica de reflexão" (Iber 2018c, p. 5; ver Hegel 2017, p. 52).

Em todas as determinações de reflexão temos o seguinte comportamento da essência: a determinação de reflexão contém em si uma contradição. A determinação de reflexão inclui a sua determinação correlativa e a exclui ao mesmo tempo. Em outras palavras: a reflexão dentro de si é um caráter do ser posto que, ao mesmo tempo, suprassume o ser posto. Então, caberá ao programa da lógica das determinações de reflexão tornar explícita esta contradição imanente na estrutura da determinação de reflexão, em que a reflexão dentro de si exclui o ser posto. Hegel fará isso dissolvendo cada determinação de reflexão (identidade, diferença, diversidade, oposição e contradição). Em cada caso, a reflexão dentro de si incluirá o ser posto. Tornar explícita a contradição da determinação de reflexão significa mostrar que ela é mero momento de uma unidade mais elevada, da unidade do fundamento que é a contradição dissolvida.

A essência está sob o poder do ser posto refletido dentro de si, o que a impede de desenvolver a identidade plena da essência. Isso apenas será alcançado com o fundamento. "Apenas no fundamento a essência 
alcançará sua explicitação, porque com a dissolução da contradição das determinações de reflexão autossubsistentes, ela se torna novamente livre como instância ponente. No fundamento, a essência está posta como essência" (Iber 2018c, p. 5).

Porém, aqui temos ainda a alienação da essência na sequência das determinações de reflexão (o ser posto como reflexão dentro de si): identidade, diferença, diversidade, oposição e contradição. O conflito interno das determinações de reflexão autossubsistentes conduz à contradição.

As determinações de reflexão estão no fundamento dos princípios da lógica formal e da metafísica tradicional (o princípio da identidade, da diversidade, do terceiro excluído e da contradição excluída). Esses princípios são a fixação das determinações por meio do entendimento, o que causa a alienação da reflexão em relação a si mesma. Mas a lógica dialética mostra que as determinações de reflexão são susceptíveis de um tratamento racional. A lógica das determinações de reflexão é uma apresentação crítica da alienação da reflexão no entendimento reflexionante, na medida em que ela põe em liberdade o outro lado do ser posto, da relacionalidade das determinações que o entendimento não alcança. ${ }^{9}$

A tríade da reflexão consiste em três momentos:

\begin{tabular}{|l|l|}
\hline Reflexão ponente: & Círculo, reflexão dentro de si \\
\hline Reflexão exterior: & Dualismo, reflexão para dentro de outro \\
\hline Reflexão determinante: & $\begin{array}{l}\text { Contradição, reflexão para dentro de } \\
\text { outro como reflexão dentro de si }\end{array}$ \\
\hline
\end{tabular}

A reflexão se efetua como retorno circular para dentro de si, como exteriorização em relação ao outro e como auto-exteriorização nas determinações de reflexão, o que é equivalente à alienação da reflexão de si mesma. A alienação da reflexão está definida pela exteriorização sem retorno completo. Sob o título das determinações de reflexão, Hegel critica

9 Federico Orsini observa que as determinações de reflexão não podem ser identificadas simplesmente com os princípios da lógica formal e da metafísica tradicional (o princípio da identidade, da diversidade, do terceiro excluído e da contradição excluída). Esses princípios são a fixação das determinações por meio do entendimento, que é a alienação da reflexão em relação a si mesma nessas determinações. Mas a lógica dialética explicita as determinações de reflexão como um processo de determinação da razão especulativa. Ou seja, a lógica dialética apresenta a crítica da alienação da reflexão no entendimento reflexionante, e, ao mesmo tempo, a relacionalidade das estruturas da razão objetiva reflexiva. 
as categorias da lógica e da metafísica tradicionais como pensamentos alienados do pensar, atravessados por contradições. Marx retoma a teoria hegeliana da reflexão como alienação para decifrar a estrutura do fenômeno central da sociedade moderna. Ele critica a propriedade privada, que exclui os trabalhadores dos produtos do seu trabalho, como alienação social. $\mathrm{O}$ objeto da crítica é, em ambos os pensadores, a contradição, seja no pensar tradicional seja na realidade social alienada.

\section{Trabalho: exteriorização e alienação no jovem Marx}

O ponto de comparação entre a teoria da reflexão hegeliana e marxiana é a teoria da alienação. Em seus primeiros escritos, Marx já discute modalidades distintas de alienação (e.g., a alienação religiosa, filosófica e política), em que uma determinada entidade também adquire capacidades propriamente humanas (respectivamente a partir do exemplo de Deus, da abstração da Ideia hegeliana e do Estado). Entretanto, não obstante as especificidades e as aplicações de seu uso do conceito de alienação já permitirem marcar os contornos de seu engajamento crítico com o pensamento dos autores da Esquerda Hegeliana (especialmente Ludwig Feuerbach e Moses Hess) na Crítica da Filosofia do Direito de Hegel (1843) e em A Ideologia Alemã (1845/46), foi a partir dos Manuscritos Econômico-filosóficos (1844), quando se engaja com os trabalhos de Economia Política de autores clássicos como Adam Smith, James Mill e Jean-Baptiste Say, que o uso da categoria trabalho alienado (entfremdete Arbeit) permite efetivamente transportar "a problemática da alienação da esfera filosófica, religiosa e política para a esfera econômica da produção material" (Musto 2014, p. 64).

$\mathrm{Na}$ Crítica da Filosofia do Direito de Hegel, Marx anuncia que a tarefa imediata da filosofia é desmascarar, então, a auto-alienação nas suas formas não sagradas - na forma da crítica do direito e da política (Marx 2010, p. 146). Nos Manuscritos Econômico-filosóficos, contudo, é a alienação na esfera econômica que se torna "o pressuposto para compreender e superar as primeiras" (Musto 2014, p. 64): ela permite a Marx mostrar como os próprios produtos do trabalho tomam uma forma estranha ou hostil em relação ao produtor, na medida em que o trabalhador encerra a sua vida no objeto ("passa a pertencer ao objeto") (Marx 2015, pp. 80-1). Para Marx, essa alienação do trabalho no capitalismo aparece sob quatro aspectos distintos: na alienação do trabalhador em relação ao produto do seu trabalho; na alienação do trabalhador em relação à atividade produtiva ("de sua própria função ativa, de sua atividade vital", que "mortifica sua 
physis e arruína o seu espírito"); na alienação do trabalhador em relação ao seu "ser genérico" (Gattungswesen); e, finalmente, na alienação do trabalhador em relação aos demais trabalhadores - o "estranhamento do homem pelo [próprio] homem" (Marx 2015, pp. 84, 86). Marx entende a alienação do homem em relação ao produto do trabalho como apenas "o resumo (Résumé) da atividade, da produção". Ou seja, a alienação do trabalhador não se reduz apenas na sua relação com os produtos do seu trabalho; em vez disso, essa alienação se mostra, outrossim, na própria atividade produtiva (Marx 2015, pp. 82-3). ${ }^{10}$

Entre exteriorização (Entäußerung) e alienação (Entfremdung), existe, pois, uma distinção de gênero e espécie, de acordo com a qual toda a alienação é uma exteriorização, mas nem toda a exteriorização é uma alienação. No capitalismo, o trabalho toma a forma de uma exteriorização alienante: o trabalho não pertence ao trabalhador, e tampouco este se afirma em seu trabalho - ele não pertence ao seu ser. Nos Manuscritos Econômico-Filosóficos, Marx descreve o trabalho como "atividade vital do homem", sua "atividade de espécie", "essência espiritual" do homem, "sua essência humana". O trabalho desempenha um papel essencial na distinção entre os seres humanos e os demais animais, segundo a qual os primeiros não são mais seres puramente naturais, mas autoconscientes, com "ser para si", na medida em que deixam de consumir apenas objetos diretamente presentes em seus ambientes naturais, "sob o domínio da carência física imediata" (Marx 2015, p. 85). O trabalho como atividade tem, para Marx - tal como a atividade do espírito e do pensar em Hegel -, a estrutura da negatividade, isto é, da exteriorização e do retorno da exteriorização para dentro de si mesmo.

O problema de uma teoria da estrutura do trabalho em que este atua na exteriorização da subjetividade na objetividade permeia a trajetória intelectual de Hegel desde o período de Jena e perpassa a filosofia do direito da maturidade. Embora o problema da alienação colocado na forma de Positivität já aparecesse em seus primeiros escritos, à época da Fenomenologia do Espírito a alienação passa a configurar-se como uma espécie particular da atividade humana, que dá origem a formações sociais específicas (Lukács 1975). Em Der Junge Hegel (O jovem Hegel), Lukács refere que Hegel começa a utilizar o conceito de exteriorização à medida que passa a interessar-se pelos avanços da economia política, no final do período de Frankfurt, e desenvolve sua tríade básica (necessidade,

10 O tradutor dos Manuscritos traduz entfremdet como "estranhado". Nós optamos por "alienado" para manter a coerência terminológica com a tradução da Doutrina da Essência de Hegel e com o mesmo termo usado por Marx. 
trabalho e gozo) juntamente com a ideia de trabalho como aniquilação do objeto (Lukács 1975). Para Hegel, a alienação consistia na dificuldade de apreender o fato de que o mundo não é externo ao Espírito, e de que apenas a atividade humana produz a eliminação do positivo.

$\mathrm{Na}$ tradução para o francês da Fenomenologia do Espírito, Labarrière e Jarkczyk explicam que, em sua "[...] acepção lógica, [alienação, Entfremdung] conota a impossibilidade de um retorno a partir de uma exterioridade radicalmente "estranha" (Fremd)", ao passo que "a saída de si que expressa a interioridade como exterioridade se expressa através do termo "exteriorização" (Entäußerung)" (1993, nota de rodapé na p. 82). O neologismo externação, entendido como "simples saída de si" (Jarkczyk 2004, p. 118), utilizado para traduzir Äußerung, distingue-se tanto de "exteriorização" quanto de "alienação" na tradução francesa da Ciência da Lógica, e expressa uma situação em que o sujeito não se torna completamente externo a si, em que não há um esvaziamento completo de seu interior no exterior. ${ }^{11}$ Em vez disso, "mantém seu caráter interior ainda distinto do exterior, com o qual ele, ao mesmo tempo, se relaciona" (Iber 2018d, p. 130). Trata-se de uma distinção que Hegel desenvolveria na explicitação das figuras fenomenológicas, bem como na Doutrina da Essência, onde interior e exterior formam a dualidade da "relação essencial" (segunda secção).

Na medida em que Hegel denomina a exteriorização do pensar na oposição sujeito-objeto igualmente como alienação, a exteriorização acaba sendo tomada como alienação. A partir daqui, começa-se a delinear a crítica de Karl Marx. Se, por um lado, Marx atribui a Hegel o mérito de, por exemplo, na secção "B. Consciência-de-si" da Fenomenologia do Espírito, ter logrado apreender "[...] a essência do trabalho e [conceber] o homem objetivo, verdadeiro, porque homem efetivo, como o resultado de seu próprio trabalho" (Marx 2015, p. 123); por outro, Hegel acabaria por, ainda assim, inserir-se no ponto de vista da economia política clássica, na medida em que "[...] vê somente o lado positivo do trabalho, não seu [lado] negativo" (Marx 2015, p. 124). Embora contenha os gérmens de sua própria crítica, Marx assinala que, como crítica da alienação, a Fenomenologia do Espírito permanece dentro da alienação, pois apresenta somente a suprassunção teórica da alienação, "que deixa existir a realidade alienada e, ao mesmo tempo, acredita tê-la superado, na medida em que

11 Ver também Hegel, Georg Wilhelm Friedrich. Ciência da Lógica: 2. A doutrina da essência. Trad. Christian G. Iber; Federico Orsini. Petrópolis: Vozes, 2017, p. 24; Meneses, Paulo. Entfremdung e Entäusserung. Ágora Filosófica, v. 1, nº 1, pp. 27-42, 2001. 
ela é tomada como "autoconfirmação" da autoconsciência pensante" (Iber 2018d, p. 128; Marx 2015, p. 125).

Para Marx, "na medida em que [o trabalho] não reserva nada de sua essência" e, "em sua exposição completa de sua essência, altera e consuma sua própria essência" (Iber 2018d, p. 130), o ser humano se exterioriza. Contudo, no trabalho sob o modo de produção capitalista, o ser humano também se aliena: a conexão entre os dois conceitos, alienação e exteriorização, consiste, pois, no fato de que, em sua exteriorização, a atividade é "impedida no seu retorno para dentro de si mesma", de tal modo que a alienação separa essa conexão entre exteriorização e retorno da exteriorização. Ou seja, enquanto que por exteriorização se entenderia o fato de que o trabalho produz um produto externo, por alienação dever-se-ia entender o fato de que "o produto se torna um alheio pela sua ocupação pela propriedade privada" (Iber 2018d, p. 131). Para Marx, a alienação não se relaciona apenas com o pensar ou com o espírito, mas com as relações materiais que constituem a sociedade. Com efeito, a norma imanente seria o estar junto a si mesmo do ser humano no seu outro, tanto no pensar como na realidade social, o que, por sua vez, implica uma crítica ao trabalho alienado que produz a propriedade privada e que se apropria dos resultados do trabalho dos quais os trabalhadores estão excluídos. Ainda assim, a relação excludente do trabalho alienado e da propriedade privada é uma oposição que se desenvolve no sentido da contradição, uma relação que tende à dissolução.

\section{Explicação de Marx da propriedade privada recorrendo à lógica hegeliana das determinações de reflexão ${ }^{12}$}

Nos Manuscritos Econômicos-filosóficos, de 1844, Marx esclarece em três passagens a relação da propriedade privada enquanto relação entre trabalho e capital com ajuda da lógica das determinações de reflexão de Hegel. A propriedade privada é a relação fundamental da sociedade burguesa; contudo, ela é uma relação excludente e, como a relação da essência em Hegel, uma relação da negatividade. Como tal, a relação da propriedade privada é a causa da pobreza e da riqueza, tal como a relação do trabalho e do capital na sociedade moderna.

Na primeira passagem, Marx parte da propriedade privada como relação fundamental (ver Marx 2015, p. 93). A relação da propriedade privada se mostra como relação entre dois correlatos: trabalho e capital. $\mathrm{O}$ fato

12 A lógica das determinações de reflexão se encontra no $2 .^{\circ}$ capítulo da lógica da essência de Hegel. Cf. Hegel 2017, pp. 53-92. 
de, por um lado, a propriedade privada enquanto trabalho e, por outro, a propriedade privada enquanto capital se relacionarem uma com a outra é esclarecido com a ajuda da lógica hegeliana da essência.

$\mathrm{Na}$ lógica das determinações de reflexão, a essência inteira como negatividade que se relaciona consigo se apresenta na sua diferencialidade interna primeiramente como identidade e diferença. Identidade e diferença são produtos da relação da essência como negatividade absoluta. A relação da diferença da identidade e da diferença (= a diferença absoluta) se determina progressivamente no sentido da relação da diversidade de igualdade e desigualdade, até à relação de oposição do positivo e do negativo, que passa para a contradição do positivo e do negativo. Na contradição, a essência como relação da negatividade se suprassume finalmente e regressa a seu fundamento (cf. Iber 2018).

Tanto a atividade humana enquanto trabalho, a redução do ser humano à "existência abstrata" de "um puro homem que trabalha" (Marx 2015, p. 93), como a "produção do objeto da atividade humana como capital" são produtos da relação da propriedade privada. Por um lado, o ser humano que - excluído da riqueza objetiva - exerce trabalho assalariado para o capital, vive no "seu pleno nada" e, no caso do desemprego, está em perigo de "precipitar-se diariamente de seu pleno nada no nada absoluto e, portanto, na efetiva (wirkliche) não existência [Nichtdasein $=$ não ser aí]" que ameaça sua vida; por outro lado, com o capital extingu-se "toda determinidade natural e social do objeto", porque este tem sua utilidade apenas para o capital. O capital é indiferente em relação ao seu conteúdo objetivo. Como valor monetário, o capital pode ser investido em quaisquer bens materiais. Quando a propriedade privada toma a forma do capital, deixa de ser confundida ingenuamente com relações puramente humanas (propriedade privada da escova de dentes, da bicicleta etc.).

A propriedade privada aliena o ser humano da própria atividade que a produziu, na medida em que o separa do produto do seu próprio trabalho e torna independente o "objeto da atividade humana", separando-o da sua unidade com a atividade e transformando-o em capital. Aqui se revela a contradição da propriedade privada. A atividade que deveria efetivar a plenitude do ser humano, o trabalho, se torna a sua aniquilação quando o trabalho se torna trabalho assalariado, ao serviço da propriedade privada. A contradição da propriedade privada torna-se evidente na auto-negação e auto-exclusão do trabalho como atividade que visa a satisfação das carências do ser humano. 
A propriedade privada é, como relação do trabalho e do capital, uma oposição que, no auge da contradição, conduz necessariamente ao declínio de toda a relação. Esta caracterização segue a determinação progressiva da oposição do positivo e do negativo para a contradição dessas determinações em Hegel. Na contradição, ambos os correlatos da relação "vão ao fundo" e, como diz Hegel, "regressam a seu fundamento" (Hegel 2017, p. 82). Em suma, como relação excludente, a propriedade privada tem por correlatos o trabalho e o capital, que se relacionam numa oposição um com o outro e entram em contradição um com o outro - o que, por fim, conduz ao declínio de toda a relação. Devido ao seu caráter contraditório, a propriedade privada não é, no final de contas, sustentável. Em vez disso, a propriedade privada é tornada sustentável apenas pelo Estado moderno e o seu poder.

Na segunda passagem (ver Marx 2015, pp. 97-98, notas de rodapé suprimidas), Marx explica o decurso "do movimento da propriedade privada" (p. 97) como relação entre trabalho e capital. O movimento parte de uma "unidade imediata", na qual o trabalho e o capital ainda estão unidos. No caso da unidade imediata do trabalho e do capital, trata-se da propriedade que se baseia no trabalho próprio dos pequenos camponeses e dos artífices. Por meio da separação do trabalho e da propriedade que surge com a monopolização dos meios de produção pela propriedade privada, o trabalho e o capital entram em tensão: nessa tensão, por um lado, elevam-se e fomentam-se "reciprocamente enquanto condições positivas"; e, por outro lado, excluem-se mutuamente como oposição. Na oposição entre capital e trabalho - na qual se sabem como não ser aí e procuram arrancar seu ser aí do outro (por exemplo, o salário e o ganho desenvolvem-se em sentido contrário) -, ambos entram em "oposição [...] um contra si mesmo".

Como oposição contra si mesmo, cada correlato da oposição é ele mesmo e seu outro e é, por isso, contraditório. O capital é, enquanto "trabalho acumulado", ele mesmo e seu outro, o trabalho. Ao mesmo tempo, decompõe-se também "em si e nos seus juros", isto é, em capital material (propriedade dos meios de produção) e capital monetário. Por exemplo, caso o capitalista não possa mais pagar os juros do capital monetário, tem que se sacrificar como capitalista e "decai na classe trabalhadora". Também o trabalhador pode tornar-se capitalista, "mas só excepcionalmente".

$\mathrm{Na}$ Ciência da Lógica, Hegel apresenta essa inversão dos momentos da oposição quando aborda o positivo e o negativo. Ambos se mostram como o outro de si mesmos. O positivo e o negativo têm seu outro tanto na sua relação com seu outro quanto neles mesmos. Assim, o positivo e o negativo são negativos um em relação ao outro: estão em oposição um ao outro e, ao mesmo tempo, em oposição a si mesmos. Para Hegel, essa inversão 
pertence à natureza das determinações de reflexão (cf. lógica da essência. Cap. 2. C. A contradição. Observação 1, Hegel 2017, pp. 83-86).

Enquanto "momento do capital" (Marx 2015, p. 98), o trabalho como dedução do ganho impõe "custos" e é, portanto, um ítem negativo, que precisa de ser minimizado. O salário se apresenta como "sacrifício do capital". Como trabalho assalariado, o trabalho se decompõe "em si e no salário". O trabalhador é como que "ele mesmo um capitalista", porque trata seu trabalho como "mercadoria". Entre capital e trabalho existe uma "oposição recíproca hostil" que é mantida politicamente pelo Estado moderno.

$\mathrm{Na}$ terceira passagem (Marx 2015, p. 103), Marx usa explicitamente o conceito de contradição da lógica hegeliana da essência. Marx explica a "oposição entre sem propriedade e propriedade", quer dizer, entre pobreza e riqueza, mediante a "oposição entre o trabalho e o capital". Na oposição entre trabalho e capital, a oposição entre pobreza e riqueza é apreendida "em sua relação ativa, em sua relação interna" e, com isso, como "contradição". $\mathrm{O}$ trabalho como "essência subjetiva da propriedade privada enquanto exclusão da propriedade" produz seu outro, o capital, como dominação sobre si mesmo. Inversamente: o capital, "o trabalho objetivo enquanto exclusão do trabalho", produz o trabalho como trabalho assalariado.

"Sem o movimento avançado da propriedade privada", a oposição da propriedade privada" assume a "primeira figura" da oposição "ainda indiferente" da pobreza e da riqueza, mas que ainda não aparece posta ou produzida pela própria propriedade privada. Como relação excludente da oposição entre trabalho e capital, a propriedade privada mostra-se causadora da oposição entre pobreza e riqueza - como "relação desenvolvida da contradição, e, por isso, uma relação enérgica que tende à solução (melhor: dissolução)".

Para Marx, a dissolução da contradição é inevitável, porque a relação da contradição entre os correlatos trabalho e capital é, ao mesmo tempo, "a contradição do trabalho alienado consigo mesmo" (Marx 2015, p. 88). Se o trabalho alienado se torna consciente de sua alienação, ele não pode permanecer alienado. Marx constata: "o trabalho alienado é a causa imediata da propriedade privada. Consequentemente, com um dos lados tem de cair também o outro" (Marx 2015, p. 88). Do lado dos trabalhadores, a dissolução da contradição põe-se inevitavelmente em movimento com a consciência da alienação, uma consciência da contradição. Ao impulso da dissolução da contradição, que se realiza com a consciência da alienação do trabalho, opõe-se o poder do Estado moderno, que insiste na manutenção da propriedade privada contraditória. 
Aqui deve ser observado o seguinte: a diferença entre Marx e Hegel não consiste, conforme entende Ernst Michael Lange, no fato de que existe em Marx - diferentemente de Hegel - uma "assimetria fundamental dos correlatos da relação da oposição" (Lange 1980, p. 191). Uma assimetria dos momentos da oposição se encontra tanto em Hegel como em Marx. Do mesmo modo que, em Hegel, o positivo é apenas a contradição em si e o negativo é a contradição posta, em Marx, a contradição do capital como "trabalho acumulado" funda-se na "contradição do trabalho alienado consigo mesmo" (Marx 2015, p. 88). A diferença entre Hegel e Marx consiste unicamente no fato de que Hegel examina as determinações de reflexão nos moldes da lógica, ao passo que Marx as emprega no contexto científico da crítica da economia política - uma ciência específica. Apesar dessa aplicação, o seu significado não se altera.

A assimetria das determinações da contradição é também a razão pela qual o "regresso ao fundamento", em Hegel, procede essencialmente por meio da negatividade posta do negativo, e em Marx por meio da consciência da contradição dos trabalhadores. Qual é o resultado da dissolução da contradição em Hegel e Marx? Em Hegel, com a dissolução da contradição, a essência enquanto reflexão encontra sua identidade positiva em sua negatividade; em Marx, com a dissolução da contradição da relação do capital e do trabalho, os trabalhadores podem apropriar-se da organização do próprio trabalho social, com vista a suprassumir sua alienação e "estar junto de si mesmos" no seu outro objetivo, isto é, nos produtos de seu trabalho.

Para a emancipação da sociedade em relação à propriedade privada, para a qual só os trabalhadores dispõem de recursos materiais, é necessária a "forma política da emancipação dos trabalhadores" (Marx 2015, p. 88), quer dizer, a luta contra o Estado moderno que apoia a propriedade privada por meio de seu poder. Para Marx, na emancipação dos trabalhadores em relação à propriedade privada capitalista está contida também a emancipação "humana universal", "porque a opressão humana inteira está envolvida na relação do trabalhador com a produção, e todas as relações de servidão são apenas modificações e consequências dessa relação" (Marx 2015, p. 89). A emancipação humana forma o análogo marxiano do "retorno ao fundamento" de Hegel.

\section{Considerações finais}

Qual é a diferença entre Hegel e Marx no que diz respeito à teoria da reflexão como exteriorização e alienação? Hegel desenvolve sua teoria da 
reflexão na Doutrina da Essência, que examina a atividade do pensar como exteriorização: ou seja, a reflexão realiza um movimento de exteriorização e retorno da exteriorização. Na lógica da essência, a reflexão ainda não está consumada. Trata-se como que de um retorno reduzido à metade, isto é, a reflexão e seu retorno permanecem na exterioridade. Nesse sentido, a reflexão está alienada. O retorno ainda não suprassume, completamente, a exteriorização. Isso distingue a lógica da essência da lógica do conceito: na essência, o retorno da reflexão da sua exteriorização permanece marcado pela alienação; ao passo que no conceito o movimento da reflexão supera essa deficiência.

Para Marx, o mundo objetivo não pode ser um produto da criatividade do conceito teórico. Apenas pode ser transformado pela prática. Isso significa que a racionalidade do mundo e a sua reflexividade não são o produto do conceito, mas da prática social. O conceito apenas pode antecipar essa racionalidade no pensar, mas ela é realizada apenas pela atividade prática do ser humano. A razão entra na realidade pela práxis. Hegel defende um idealismo absoluto como unidade do idealismo e do realismo. Marx propõe um materialismo verdadeiro como naturalismo realizado, ou seja, um humanismo como unidade do idealismo e do realismo. O ser humano não é, em primeiro lugar, uma essência espiritual como em Hegel, mas uma essência natural-espiritual. É isso que faz a verdadeira diferença entre Hegel e Marx (ver os Manuscritos de 1844).

\section{Referências Bibliográficas}

Hegel, Georg Wilhelm Friedrich (2017), Ciência da lógica: 2. A doutrina da essência. Trad. Christian G. Iber; Federico Orsini. Petrópolis: Vozes.

Iber, Christian (2018), O desenvolvimento da essência como reflexão e a lógica das determinações de reflexão. Manual renovado 2018-01. Porto Alegre.

Iber, Christian (2018a), A reflexão ponente. Seminário: A contradição na Lógica da essência de Hegel. PUCRS/PPGFILOSOFIA: Porto Alegre.

Iber, Christian (2018b), A passagem da reflexão exterior para a reflexão determinante. Seminário: A contradição na Lógica da essência de Hegel. PUCRS/PPGFILOSOFIA: Porto Alegre. 
Iber, Christian (2018c), A reflexão determinante. Seminário: A contradição na Lógica da essência de Hegel. PUCRS/PPGFILOSOFIA: Porto Alegre, 2018/1 (c).

Iber, Christian (2018d), Revolução como negação da negação? Revista Dialectus, v. $5, \mathrm{n}^{\circ} 12$, pp. $121-138$.

Jarczyk, Gwendoline (1984), O conceito do trabalho e o trabalho do conceito em Hegel. In: Filosofia Política 1. Porto Alegre: L\&PM.

Lange, Ernst Michael (1980), Das Prinzip Arbeit. Drei metakritische Kapitel über Grundbegriffe, Struktur und Darstellung der Kritik der Politischen Ökonomie von Karl Marx. Frankfurt am Main/Berlin/Wien: Ullstein.

Lukács, Georg (1976), The Young Hegel: Studies in the Relations between Dialectics and Economics. Trad. Rodney Livingstone. Cambridge: MIT. Marx, Karl (2015), Manuscritos econômico-filosóficos. Trad. Jesus Ranieri. São Paulo: Boitempo Editorial.

Marx, Karl (2010), Crítica da filosofia do direito de Hegel. Trad. Rubens Enderle; Leonardo de Deus. São Paulo: Boitempo.

Musto, Marcello (2014), Revisitando a concepção de alienação em Marx. In: ROIO, Marcos Del (Org.). Marx e a dialética da sociedade civil. Marília: Cultura Acadêmica, pp. 61-94.

\section{RESUMO}

A teoria da reflexão de Hegel desempenha um papel tanto lógico quanto ontológico na teoria do trabalho e da propriedade privada de Marx. Qual é o ponto de comparação entre a teoria hegeliana da reflexão e a teoria marxiana? A teoria da alienação. Em Hegel econtramos a alienação do pensamento no pensar reflexionante - o modo de operação do entendimento; em Marx, a alienação do trabalho sob a propriedade privada. Como atividade, o trabalho tem, de acordo com Marx - tal como a atividade do pensar, em Hegel - a estrutura da negatividade: a estrutura da exteriorização e do retorno a si mesmo. Nos Manuscritos Econômicos e Filosóficos (1844), em particular, Marx desenvolveu uma teoria da exteriorização do trabalho na qual a alienação impede que este cumpra o seu retorno a si. O trabalho torna-se alienado, sai de si e permanece fora de si, pois é apropriado pela propriedade privada.

Palavras-Chave: Reflexão - Alienação - Hegel - Marx 


\begin{abstract}
Hegel's theory of reflection plays both a logical and ontological role in Marx's theory of labour and private property. What is the point of comparison between a Hegelian and a Marxian theory of reflection? The theory of alienation. In Hegel, one has the alienation of thought in reflective thinking - the understanding's mode of operation; in Marx, the alienation of labour under private property. As an activity, labour has, according to Marx - like the activity of thinking, in Hegel the structure of negativity: the structure of externalization and return to the self. In the Economic and Philosophic Manuscripts (1844), in particular, Marx developed a theory of the externalization of labour in which alienation prevents the latter from fulfilling its return to itself. Labour becomes alienated, leaves itself and remains outside of itself, for it is appropriated by private property.
\end{abstract}

Keywords: Reflection - Alienation - Hegel - Marx 